\title{
A new species of Sarcofahrtiopsis (Insecta, Diptera, Sarcophagidae) from mangrove forests in the Brazilian Amazon, with a key to species identification
}

Fernando da Silva CARVALHO-FILHO ${ }^{*}$, Caroline Costa de SOUZA $^{1}$, Jéssica Maria Menezes SOARES ${ }^{1}$

1 Museu Paraense Emílio Goeldi, Coordenação de Zoologia, Entomologia. Avenida Perimetral, 1901, Bairro Terra Firme - Belém, Pará, Brazil - CEP 66077-830.

*Corresponding author: fernandofilho@museu-goeldi.br

ABSTRACT

A new species of Sarcofahrtiopsis Hall, 1933, S. terezinhae sp. nov., is described based on male specimens collected in traps baited with rotting crabs in a mangrove forest in the state of Pará, eastern Brazilian Amazon. This species differs from congeneric species in having vesica with a row of toe-like projections. We provide a key to the species of the genus.

KEYWORDS: flesh fly, Calyptratae, Oestroidea, Brazil, Pará

\section{Uma nova espécie de Sarcofahrtiopsis (Insecta, Diptera, Sarcophagidae) de florestas de mangue na Amazônia brasileira, com uma chave de identificação}

\section{RESUMO}

Uma nova espécie de Sarcofahrtiopsis Hall, 1933, S. terezinhae sp. nov., é descrita com base em espécimes machos coletados com armadilhas contendo caranguejo em decomposição como isca em áreas de mangue no Pará, na Amazônia brasileira. Esta espécie difere das demais espécies do gênero por apresentar vesica com uma fileira de projeçôes parecidas com dedos. Uma chave para as espécies do gênero é apresentada.

PalaVRaS-ChaVE: mosca, Calyptratae, Oestroidea, Brasil, Pará 


\section{INTRODUCTION}

The family Sarcophagidae (flesh flies) is the second largest family in the superfamily Oestroidea, with some 173 genera and 3,094 species (Pape et al. 2011). The family is present in all biogeographical regions except Antarctica. While these flies occur in many types of environments, some occur in very specific habitats, such as grasslands, mangroves, oceanic beaches and inundated forests (Pape and Dahlem 2010).

The Brazilian Amazon has one of the country's largest areas of mangroves (Herz 1991), and some species of animals and plants are endemic to this environment. Few entomological studies have been made in mangroves, and most surveys of flesh flies in the Amazon have been restricted to non-inundated forests (Esposito and Linhares 2002; Sousa et al. 2011), which are the most accessible and frequently sampled environments.

Sarcofahrtiopsis Hall, 1933 comprises 13 species of small to medium-sized flies (3-6 $\mathrm{mm}$ in length) distributed from the southern United States (Florida and Texas) to northern South America. Most species are from Central America, including the Antillean Islands, and only two have been recorded from Brazil: S. cuneata (Townsend, 1935) (Amazonas, Ceará, Maranhão, Pará, Pernambuco, Rio de Janeiro) and S. cupendipe CarvalhoFilho \& Esposito, 2014 (Pará) (Pape 1996; Carvalho-Filho et al. 2014). The biology of most of these species is unknown, but some have been reared from dead crabs (Pape and Méndez $2002 ; 2004)$, and from feces accumulated in the roosts of diskwinged bats, Thyroptera spp. Spix, 1823, in young coiled leaves of Heliconia L. and related banana-like plants (Pape et al. 2002, Carvalho-Filho et al. 2014).

In this paper we describe a new species of Sarcofahrtiopsis collected in a mangrove forest in the Brazilian Amazon and provide a key to congeneric species based on males.

\section{MATERIALS AND METHODS}

Specimens were collected in two mangrove forests in the state of Pará, in the eastern Brazilian Amazon: (1) on the margin of the Marapanim River ( $0^{\circ} 51^{\prime} 40.57^{\prime \prime}$ S, $\left.47^{\circ} 40^{\prime} 6.36^{\prime \prime W}\right)$, in the village of Calafate, municipality of Magalhães Barata; and (2) in the village of Itapuá $\left(0^{\circ} 49^{\prime} 46.23^{\prime \prime} \mathrm{S}, 48^{\circ} 8^{\prime} 19.11^{\prime \prime} \mathrm{W}\right)$, municipality of Vigia de Nazaré. These localities are located in the same region, that is tropical, warm and humid. The annual average temperature is $26^{\circ} \mathrm{C}$ and precipitation varies between 2500-3000 mm (Bêrredo et al. 2008), with a dry season with mean monthly precipitation less than $50 \mathrm{~mm}$, lasting from July to December (Fisch et al. 1998). The mangrove forests are composed mainly by Avicennia germinans (L.) Stearn., Avicennia schaueriana Stapf and Leechm ex Moldenke., Laguncularia racemosa (L.) Gaertn. f. and Rhizophora mangle L. (Menezes et al. 2008) and they are subject to a macrotidal regime (Schaeffer-Novelli et al. 2000), with tidal amplitude varying between $4 \mathrm{~m}$ and $7.5 \mathrm{~m}$ (Souza-Filho 2005).

Specimens of flesh flies were collected in traps made of 2-liter plastic bottles similar to those used by Amat (2010), but without alcohol, that were tied to the tree trunks about $1.50 \mathrm{~m}$ from the ground. They were baited with rotting crab (Ucides cordatus L.), shrimp, fish and beef lung. Were utilized 15 traps for each kind of bait, totalizing 60 traps, that were exposed for $48 \mathrm{~h}$ in the field. We obtained 805 flesh flies, four of which were utilized in the description of the new species. Specimens were collected under ICMBio/SISBIO license 8874-1. They were deposited in the entomological collection of Museu Paraense Emílio Goeldi (MPEG), Belém, Brazil.

Preparations of genitalia were made by removing the abdomen of a mounted specimen (dried specimens were first relaxed in high humidity) and clearing it in $10 \% \mathrm{KOH}$ for $24 \mathrm{~h}$., after which it was washed in distilled water, and neutralized with acetic acid and $70 \%$ ethanol. The cleared abdomen was transferred to glycerin for further dissection, examination and drawing with the aid of a drawing tube attached to a compound microscope. Abdomen and genitalia were stored in plastic microvials pinned beneath the source specimen.

Terminology followed Cumming and Wood (2009) for external morphology and Giroux et al. (2010) for male terminalia. Label data are presented in verbatim quotation with individual lines separated by a forward slash (/) and individual labels separated by a double forward slash (//). Information on specimen labels (shape and color) is given in square brackets. The key was adapted from earlier keys by Pape and Méndez (2004) and Carvalho-Filho et al. (2014).

The map with the geographic records of species was generated using the software QGIS version 2.18.10. Collecting sites indicated on the map are based on data from literature (Dodge 1965; Pape 1996; Mello and Pape 2000; Pape and Méndez 2002; 2004; Pape et al. 2002; CarvalhoFilho et al. 2014).

\section{RESULTS}

\section{Sarcofahrtiopsis terezinhae sp. nov.}

\section{Diagnosis}

Vein $R_{1}$ setose only on proximal half. Sternite 5 shieldlike with a small median convexity on the posterior margin. Surstylus with distal portion curved posteriorly (Figure 1A). Pregonite with dorsal margin bearing a row of long and stout setae which are sligthly swollen apically (Figure 1C). Postgonal apodeme elongate (Figure 1C). Vesical extension elongate and without bifurcation apically (Figure 1D). Vesica with a row of toe-like projections on the apical margin (Figure 1D). 

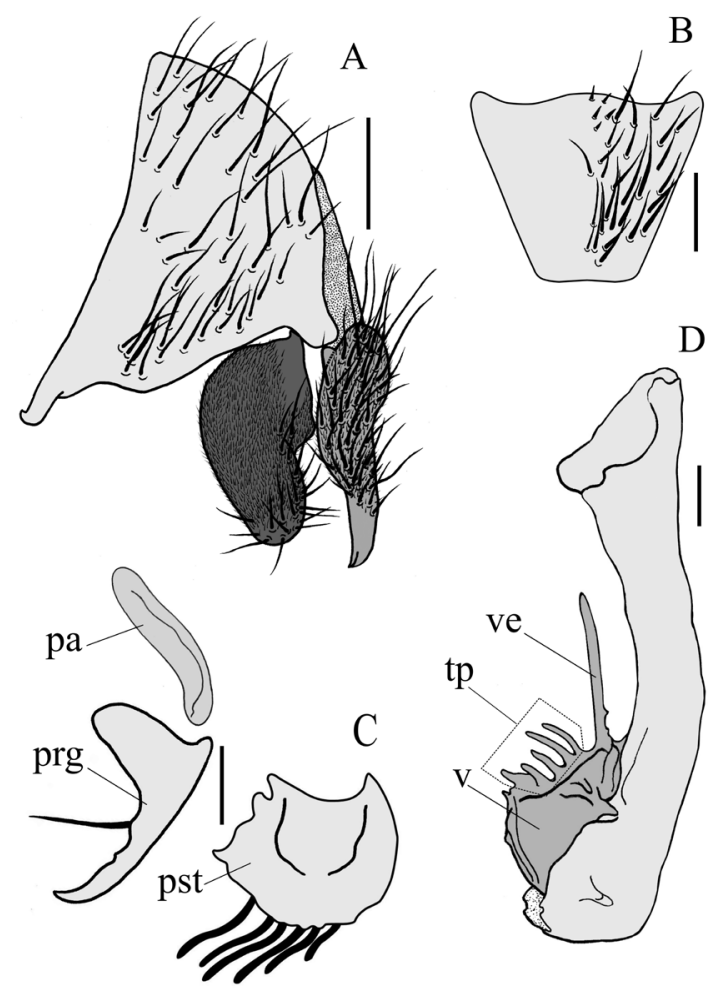

Figure 1. Sarcofahrtiopsis terezinhae n. sp., male paratype. A. Epandrium, surstylus and cercus, left lateral view; B. Sternite 5 , ventral view; C. Right gonite, lateral view; D. Phallus, lateral view. Scale bars $=0.1 \mathrm{~mm}$, except in Fig. $1 \mathrm{~A}$ where it represents $0.2 \mathrm{~mm}$. Abbreviations: $\mathrm{pa}=$ postgonal apodeme, $\underline{\mathrm{prg}}=$ pregonite $\underline{\mathrm{ptg}}=$ postgonite $; \underline{\mathrm{t}}=$ toe-like projections $; \underline{\mathrm{v}}=$ vesica; $\underline{\mathrm{ve}}$ $=$ vesical extension.

\section{Etymology}

This species is named in honour of the second author's grandmother, Terezinha de Jesus Ferreira Costa, for her hospitality during fieldwork carried out in the village of Calafate.

\section{Description}

Male. Body length: 4.63-5.10 mm $(\mathrm{n}=4)$.

\section{Head}

Fronto-orbital and parafacial plates with golden pruinosity, postocular strip light golden. Parafacial plate with a row of three fine setae along the lower part of the eye. Frontal vitta black; frontal row of four setae; one reclinate and two proclinate orbital setae. Gena and postgena yellowish grey with black setae. Antenna black; first flagellomere about three times as long as pedicel; arista long plumose in basal two thirds. Palpus and proboscis black.

\section{Thorax}

Chaetotaxy: acrostichals $0+1$, dorsocentrals $2+3$, intraalars $1+2$, supra-alars $2+3$, postpronotals 2 , postalars 2 , notopleurals 2, katepisternals 2, scutellum with marginal setae 2 , apicals 0 , discals 1 . Wing hyaline, basicosta brown, vein $\mathrm{R}_{1}$ setose on basal half, vein $\mathrm{R}_{4+5}$ setose dorsally to crossvein $\mathrm{r}-\mathrm{m}$. Legs black; forefemur with several bristles along anterodorsal and anteroventral margins; foretibia with one anteroventral and one posterior seta; midfemur with two anterior and two anteroventral setae; midtibia with one anteroventral and two posterior setae; hindtibia with two anterior, one anteroventral, and two posterodorsal setae.

\section{Abdomen}

Tergites dark brown, tergites 3 to 5 each with a band of silvery gray pruinosity anterolaterally. Sternites light brown with silvery gray pruinosity.

Terminalia. Sternite 5 shield-like, not cleft, with posterior margin sligthly sinuous and with a small median convexity, covered with long and stout setae and posteriorlly, above the convexity, with some short and spine-like setae (Figure 1B). Syntergosternite $7+8$, epandrium and cercus dark brown. Cercus short (shorther than epandrium) and curved in profile, tapering distally, with pointed apex, covered with long setae, distal third without setae and setulae. Surstylus broad, sligthly narrowed at middle, with rounded apex curved anteriorly, covered with short setulae and with long setae mainly distally (Figure 1A). Pregonite broad, shorther than postgonite, with dorsal margin bearing a row of long and stout setae, which are slightly swollen apically (Figure 1C). Postgonite claw-shaped with a long and stout seta on the anterior margin (Figure 1C). Postgonal apodeme elongate. Phallic tube elongate, narrow and tubular, slighly curved posteriorly (Figure 1D). Vesica (highlighted in dark gray) enlarged and irregular (Figure 1D); vesical extension elongated and almost straight with rounded apex (Figure 1D). In addition to the vesical extension, there are about five toe-like projections as about one-third or less longer of the total of the vesical extension length (Figure 1D).

\section{Female}

Unknown.

\section{Material examined}

Holotype male (Figure 2) labelled as follows: "Magalhães Barata, Pará, Brasil/ Vila de Calafate/ Manguezal [= mangrove forest] Açaiteua/16-18.XII.2015 [printed on rectangular white label]// Armadilha de garrafa Pet [= traps made of 2-liter plastic bottles]/ Isca de caranguejo [= crab bait]/ Cols: Souza, C.C.; Soares, J.M./ Tavares-Jesus, K.M.” [printed on rectangular white label]. Specimen [MPEG 02022668] in good condition with terminalia extended.

Paratypes: three males labelled as the holotype and one male labelled as follow: "Vigia de Nazaré, Pará, Brasil/ Vila de Itapuá/ Manguezal [= mangrove forest] Anauerá/ 15-18.X.2015 [printed on rectangular white label]// Armadilha de garrafa 


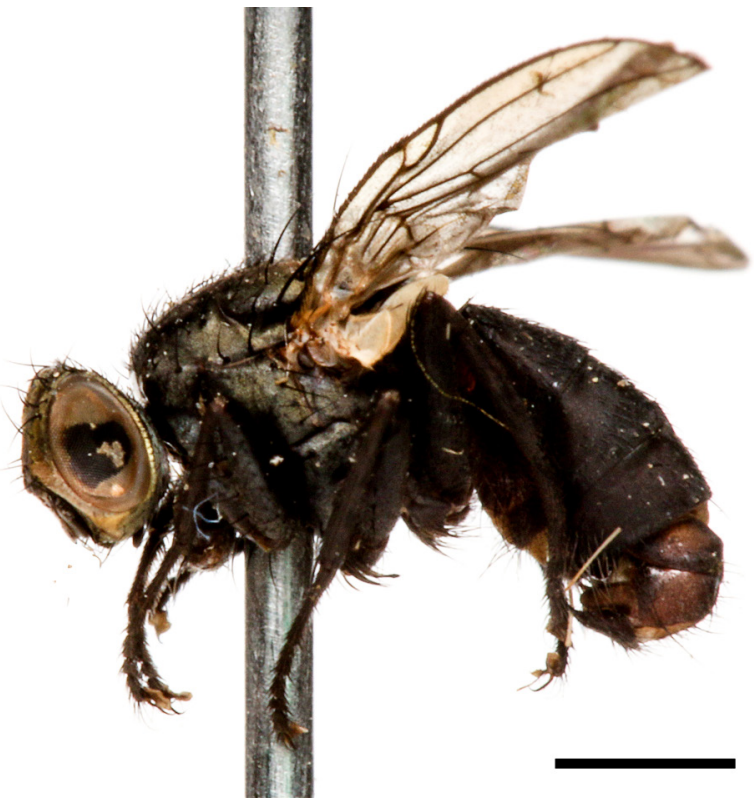

Figure 2. Sarcofahrtiopsis terezinhae $\mathbf{n}$. sp., habitus of male holotype, lateral view. Scale bar $=1.0 \mathrm{~cm}$. This figure is in color in the electronic version.

Pet [= traps made of 2-liter plastic bottles]/ Isca de caranguejo [= crab bait]/ Cols: Souza, C.C.; Soares, J.M./ Tavares-Jesus, K.M.” [printed on rectangular white label]. One paratype [MPEG 02022667] laterally flattened, anterior legs missing and terminalia glued to cardboard triangle pinned below the specimen. One paratype [MPEG 02022669] without head, abdomen, right mid leg and left hind leg. The paratype [MPEG 02022670] from Vigia de Nazaré is in good condition.

\section{Geographical record}

NEOTROPICAL_Brazil (Pará).

\section{Key to the identification of Sarcofahrtiopsis spp. (males only)}

Modified from Pape and Méndez (2004) and Carvalho-Filho et al. (2014).

Females are not included in this key since they are unknown for most of the species. Sarcofahrtiopsis diembroma Dodge, 1965 was not included because only the female is known.

1. Vein R1 setose along full length. Postgonal apodeme not elongate [Figure 3 in Carvalho-Filho et al. (2014)] .............. 2

- Vein R1 setose only proximal to the knob at level of subcostal break. Postgonal apodeme distinctly elongate [Figures 13 and 22 in Mello-Patiu and Pape (2000)]

2. Distiphallus laterally without cuticular spines [Figure 5 in Carvalho-Filho et al. (2014)]. Postgonite with tip strongly curved [Figure 3 in Carvalho-Filho et al. (2014)]. Surstylus without spines on basal half [Figure 1 in Carvalho-Filho et al. (2014)] S. cupendipe Carvalho-Filho \& Esposito

- Distiphallus laterally with minute cuticular spines [Figure 1 in Pape et al. (2002)]. Postgonite with tip gently curved [Figure 3 in Pape et al. (2002)]. Surstylus with spines on basal half [Figure 1 in Pape et al. (2002)]

S. thyropteronthos Pape, Dechmann \& Vonhof

3. Abdominal tergite 5 reddish S. baumhoveri Dodge

- Abdominal tergite 5 black 4

4. Vesica with apical margin bearing a spiny process in addition to the usual vesical extension [Figure 29 in Dodge (1965)] .... S. paterna Dodge

- Vesica without separate spiny process on apical margin, only showing the vesical extension [Figure 24 in Mello-Patiu \& Pape (2000)]

5. Vesical extension with a small or a large bifurcation [Figure 24 in Mello-Patiu and Pape (2000) and Figures 1, 2, 4 and 5 in Pape and Méndez (2004)]

- Vesical extension simple, entirely without bifurcation [Figure 4 and 13 in Mello-Patiu and Pape (2000)] 9

6. Vesical bifurcation small, mainly a subapical barb- or thornlike process [Figure 24 in Mello-Patiu and Pape (2000)] S. cuneata (Townsend)

- Vesical bifurcation large, both prongs about equally long [Figures 1, 2, 4 and 5 in Pape and Méndez (2004)] ............ 7

7. Cercus distally slightly swollen and compressed, tip blunt [Figure 3 in Pape and Méndez (2002)] S. carcini Pape \& Méndez

- Cercus gradually tapering, tip pointed [Figures 3 and 6 in Pape and Méndez (2004)] ... .... 8

8. Vesical bifurcation with prongs of about equal length, the one perpendicular to the longitudinal axis of the vesical extension set close to base [Figures1 and 2 in Pape and Méndez (2004)] S. kuna Pape \& Méndez

- Vesical bifurcation with prongs of subequal length, the one perpendicular to the longitudinal axis of the vesical extension is shortest and set just proximal to the mid point [Figures 4 and 5 in Pape and Méndez (2004)] ...... S. chiriqui Pape \& Méndez

9. Vesical extension much longer than remaining vesica and with a spade- or shovel-like flattened tip [Figure 15 in MelloPatiu and Pape (2000)] S. spathor Mello-Patiu \& Pape

- Vesical extension at most as long as remaining vesica, tip not flattened [Figure 1D, this study] 10

10. Vesica rounded or broadly oval [Figure 24 in Dodge (1965)] S. capitata (Curran) 
- Vesica more irregular, almost triangular [Figure 1D, this study]

11. Vesica with long (about one-third or less longer than the total vesical extension length) toe-like projections on the apical margin [Figure 1D, this study]. Ventral margin of vesica without a quadrate projection [Figure 1D, this study]. Surstylus with distal portion curved posteriorly [Figure 1A, this study]. Basicosta brown S. terezinhae sp. nov.

- Vesica with very small (less than a fifth of the vesical total length) spine-like projections on the apical margin [Figures 22 and 25 in Dodge (1965)]. Ventral margin of vesica with a quadrate projection [Figures 22 and 25 in Dodge (1965)]. Surstylus with distal portion not curved posteriorly [Figures 22 and 25 in Dodge (1965)]. Basicosta brown or yellowish

12. Basicosta yellowish. Vesica with 4 to 5 spines on the apical margin [Figure 25 in Dodge (1965)] S. farri Dodge

- Basicosta brown. Vesica with 8 to 10 spines on the apical margin [Figure 22 in Dodge (1965)] ....... S. jamaicensis Dodge

\section{DISCUSSION}

The new species described in here differs from congeneric species in having the vesica with about five toe-like projections (about one-third or less longer than the total vesical length) close to the vesical extensison (see Figure 1D). Sarcofahrtiopsis farri, S. paterna and S. jamaincens also show vesica with projections close to the vesical extension, however these are tiny and pointed apically.

One of the diagnostic features of Sarcofahrtiopsis is the presence of strong setae along the dorsal margin of the pregonite (Lopes 1990). However, the four species described after Lopes' work (S. baumhoveri, S. cupendipe, S. spathor, and S. thyropteronthos) did not have this feature. For this reason, Mello-Patiu and Pape (2000) did not include this feature in their diagnosis of the genus and considered it to be a diagnostic feature of a subset of species, which includes the new species described herein.

All the studied specimens were collected in mangrove forest, which suggests that $S$. terezinhae is associated with this environment. Other species of this genus also show a close association with marine coastal environments (Pape and Méndez 2002; 2004). This is the third species of Sarcofahrtiopsis described for South America (Figure 3). The other two species are associated with terra-firme forest environments.

The biology of most Sarcofahrtiopsis species remains unknown. Two species have been collected only in the feces of disk-winged bats, Thyroptera spp. (Pape et al. 2002; CarvalhoFilho et al. 2014), while $S$. cuneata has been collected in large numbers in traps baited with rotting beef lung (Sousa et al. 2011), and visiting human feces or rotting fish (Lopes

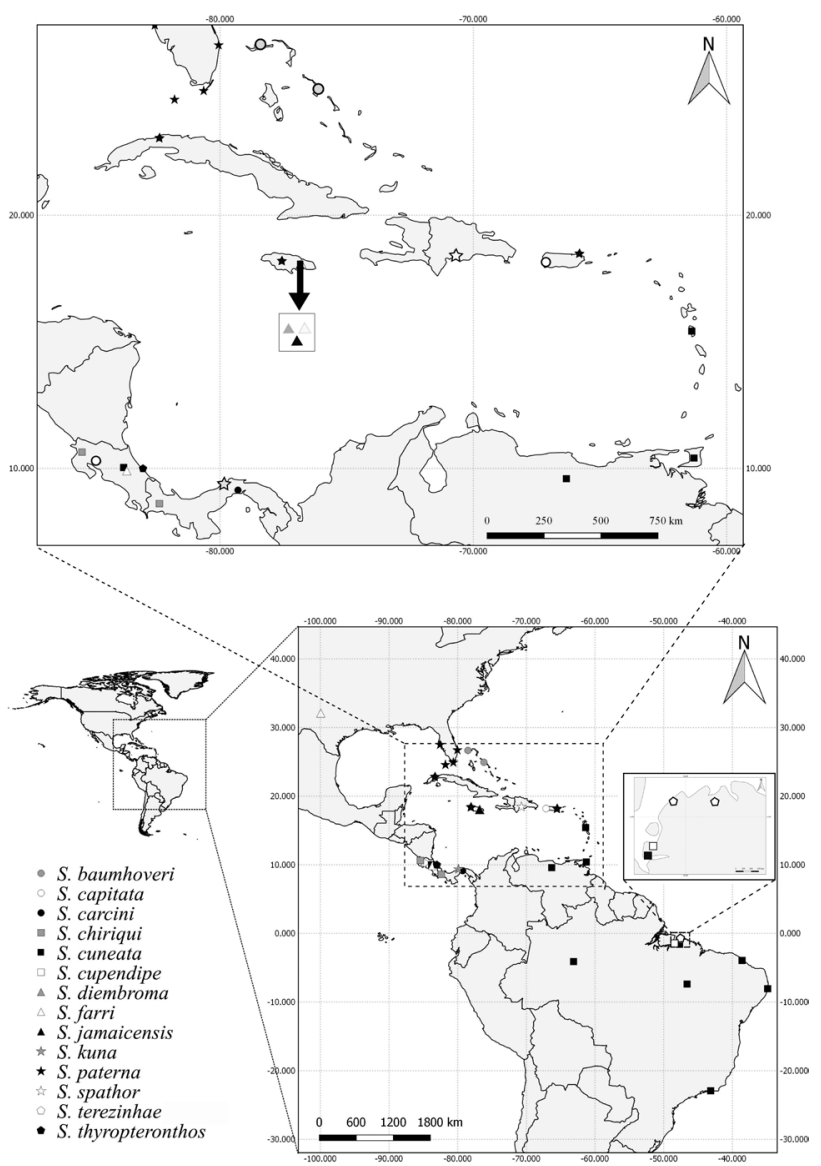

Figure 3. Geographic records of Sarcofahrtiopsis.

1973; Pape and Mendéz 2002). Sarcofahrtiopsis terezinhae was collected in traps baited only with Ucides cordatus crabs, a species common in mangroves. We hypothesize that $S$ terezinhae possibly uses dead crabs as a breeding substrate, as do other three species in the genus (Pape and Méndez 2002; 2004).

\section{ACKNOWLEDGEMENTS}

We thank Ronaldo Ferreira Costa, Valdomiro Ferreira Costa, Luiz Gustavo Andrade, Klycya Mayara Tavares and Raimundo Luiz Sousa for their help with fieldwork in the mangrove forests and Terezinha de Jesus Ferreira Costa, Rosa Mery de Morais Sousa and Luiz de Gonzaga Saldanha Sousa for their hospitality. We are grateful to Dr William L. Overal (MPEG) for reviewing the English and for suggestions.

\section{REFERENCES}

Amat, E. 2010. Notes on necrophagous flies (Diptdera: Calyptratae) associated to fish carrion in Colombian Amazon. Acta Amazonica, 40: 397-400.

Berrêdo, J.F.; Costa, M.L.; Progene, M.P.S. 2008. Efeitos das variaçóes sazonais do clima tropical úmido sobre as águas e 
sedimentos de manguezais do estuário do rio Marapanim, costa nordeste do Estado do Pará. Acta Amazonica, 38: 473-482.

Carvalho-Filho, F.S.; Esposito, M.C.; Silva, A.A. 2014. A further new species of Sarcofahrtiopsis Hall (Diptera: Sarcophagidae) associated with faeces of the disk-winged bat (Thyroptera Spix: Chiroptera) in Brazil and the redescription of the female terminalia of S. cuneata (Townsend). Zootaxa, 3889: 118-126.

Cumming, J.M.; Wood, D.M. 2009. Adult morphology and terminology. In: Brown, B.V.; Borkent, A.; Cumming, J.M.; Wood, D.M.; Woodley, N.E.; Zumbado, M. (Eds.). Manual of Central American Diptera. Vol. 1. NRC Research Press, Ottawa, p.9-50.

Dodge, H.R. 1965. The Sarcophagidae (Diptera) of the West Indies. II. Jamaica. Annals of the Entomological Society of America, 58: 497-517.

Esposito, M.C.; Linhares, A.X. 2002. Califorídeos e outros muscóides da Estação Científica Ferreira Penna. In: Lisboa, P.L.B. (Ed.). Caxiuanã populaçôes tradicionais: Meio físico e diversidade biológica. Museu Paraense Emílio Goeldi, Belém, Pará, p.579-585.

Fisch, G.; Marengo, J.A.; Nobre, C. 1998. Uma revisão geral sobre o clima da Amazônia. Acta Amazonica, 28: 101-126.

Giroux, M.; Pape, T.; Wheeler, T.A. 2010. Towards a phylogeny of the flesh flies (Diptera: Sarcophagidae): morphology and phylogenetic implications of the acrophallus in the subfamily Sarcophaginae. Zoological Journal of the Linnean Society, 158: 740-778.

Herz, R. 1991. Manguezais do Brasil. Instituto Oceanográfico. Universidade de São Paulo, São Paulo, 227p.

Lopes, H.S. 1973. Collecting and rearing sarcophagid flies (Diptera) in Brazil, during 40 years. Anais da Academia Brasileira de Ciências, 45: 279-291.

Lopes, H.S. 1990. On the genera of Sarcophagidae (Diptera) showing proclinate frontorbital bristles in males. Revista Brasileira de Biologia, 50: 279-292.

Mello-Patiu, C.A.; Pape, T. 2000. Definitions of Dexosarcophaga Townsend 1917 and Sarcofahrtiopsis Hall 1933, including two new species and a redescription of Sarcofahrtiopsis cuneata (Townsend 1935) (Diptera: Sarcophagidae). Boletim Entomologico de Venezuela, 15: 181-194.
Menezes, M.P.M; Berger, U.; Mehlig, U. 2008. Mangrove vegetation in Amazonia: a review of studies from the coast of Pará and Maranhão States, north Brazil. Acta Amazonica, 38: 403 - 420.

Pape, T. 1996. Catalogue of the Sarcophagidae of the world (Insecta: Diptera). Memoirs on Entomology, International, 8: 1-558.

Pape, T.; Blagoderov, V.; Mostovski, M.B. 2011. Order Diptera Linnaeus, 1758. In: Zhang, Z.Q. (Ed.). Animal biodiversity: An outline of higher-level classification and survey of taxonomic richness. Zootaxa, 3148: 222-229.

Pape, T.; Dahlem, G.A. 2010. Sarcophagidae. In: Brown, B.V.; Borkent, A.; Cumming, J.M.; Wood, D.M.; Woodley, N.E.; Zumbado, M. (Eds.). Manual of Central American Diptera. v. 2. NRC Research Press, Ottawa, p.1313-1335.

Pape, T.; Dechmann, D.; Vonhof, M.J. 2002. A new species of Sarcofahrtiopsis Hall (Diptera: Sarcophagidae) living in roosts of Spix's disk-winged bat Thyroptera tricolor Spix (Chiroptera) in Costa Rica. Journal of Natural History, 36: 991-998.

Pape, T.; Méndez, J. 2002. A new species of Sarcofahrtiopsis Hall, 1933 from Panama (Diptera: Sarcophagidae). Annales Zoologici, 52: 339-342.

Pape, T.; Méndez, J. 2004. Two new species of Sarcofahrtiopsis (Diptera: Sarcophagidae). Zootaxa, 485: 1-7.

Schaeffer-Novelli, Y.; Cintrón-Molero, G.; Soares, M.L.G.; Rosa, T. 2000. Brazilian mangroves. Aquatic Ecosystem Health and Management, 3: 561-570.

Sousa, J.R.P.; Esposito, M.C.; Carvalho Filho, F.S. 2011. Composition, abundance and richness of Sarcophagidae (Diptera: Oestroidea) in forests and forest gaps with different vegetation cover. Neotropical Entomology, 40: 20-27.

Souza-Filho, P.W. 2005. Costa de manguezais de macromaré da Amazônia: cenários morfológicos, mapeamento e quantificação de áreas usando dados de sensores remotos. Revista Brasileira de Geofisica, 23: 427-435.

Received: 05/02/2017

Accepted: 29/08/2017 